\title{
A review of reproduction biology and spawning/ nursery grounds of the most important Adriatic commercial fish species in the last two decades
}

\author{
Barbara ZORICA ${ }^{1 *}$, Vanja ČIKEŠ KEČ ${ }^{1}$, Nedo VRGOČ ${ }^{1}$, Igor ISAJLOVIĆ ${ }^{1}$, \\ Corrado PICCINETTI ${ }^{2}$, Milica MANDIĆ ${ }^{3}$, Bojan MARČETA ${ }^{4}$ and Ana PEŠIĆ ${ }^{3}$ \\ ${ }^{1}$ Institute of Oceanography and fisheries, Šet. I. Meštrovića 63, 21000 Split, Croatia \\ ${ }^{2}$ Laboratorio di biologia marina e pesca - Fano, Italy \\ ${ }^{3}$ University of Montenegro - Institute of Marine Biology, \\ Dobrota bb, P Box 69, 85330 Kotor, Montenegro \\ ${ }^{4}$ Fisheries Research Institute of Slovenia, \\ Spodnje Gameljne 61a, 1211 Ljubljana - Šmartno, Slovenia
}

"Corresponding author: zorica@izor.hr

\begin{abstract}
Recently, despite long-term systematic research of the Adriatic Sea ecosystem, the necessity to improve the existing protection of commercially exploited species occurred since the status of many renewable marine stocks were not in good state. In order to realise that review of scientific knowledge gather within the last two decades was required. In this paper emphasis has been placed on all the scientific knowledge concerning the reproductive biology, spawning and nursery grounds of four ecologically and economically important Adriatic fish species - sardine Sardina pilchardus, anchovy Engraulis encrasicolus, European hake Merluccius merluccius, Common pandora, Pagellus erythrinus.

Main aim of this review was to establish new scientific platform that in near future should result with better conservation measures that will insure long-term sustainability of exploited marine living resources.
\end{abstract}

Key words: sardine, anchovy, hake, Common pandora, spawning, Adriatic Sea

\section{INTRODUCTION}

In the Adriatic Sea, the northernmost shallow semi-enclosed basin in the Mediterranean, fishery is generally well developed and represent an important branch of its coastline countries economy. According to available official catch data within this area all fleet segments (from small-scale fishery vessels to large trawlers) are present but due to obtained catches and its commercial values three types of fishing gears are highlighted - purse seiners and midwater trawlers targeting small pelagics and bottom trawlers targeting demersal fish (UNEP-MAP-RAC/ SPA., 2014). 
The Adriatic pelagic fleet targeting small pelagic fish species is consisted of purse seiners (eastern Adriatic) and midwater pelagic pair trawlers (western Adriatic). Two of the most abundant, ecologically and economically important small pelagic fish species are the sardine, Sardina pilchardus, and the anchovy, Engraulis encrasicolus. Both of them are widely distributed throughout the whole Adriatic Sea as well as in Mediterranean basin and along the area of the north-eastern Atlantic (WHITEHEAD et al., 1988). Those small pelagic fish species are known as short-lived and fast-growing fish with protracted spawning season during which they tend to release their spawning products multiple times (MORELLO \& ARNERI, 2009).

Contrary to pelagic fishery, Adriatic demersal fishery is targeting more than two species actually this type of fishery is known as multispecies. Among many targeted demersal fish species, the most important, by far, is European hake, Merluccius merluccius (Linnaeus, 1758), along with red mullet (Mullus barbatus), common sole (Solea vulgaris) and Norway lobster (Nephrops norvegicus). This nectobenthonic species is distributed throughout the Adriatic and entire Mediterranean Sea, while in the Atlantic region it is found from Norway to Mauritania (JARDAS, 1996; RELINI et al., 1999). It is long-lived species and as a batch spawner (MURUA \& SABORIDO-REY, 2003) tend to spawn throughout the year with two spawning peaks (KARLOVAC, 1965; JUKIĆ \& PICCINETTI; 1987). Apart from European hake, within this review Common pandora, Pagellus erythrinus (Linnaeus, 1758), is analysed as commercially important benthopelagic fish species. Common pandora is widely distributed in the Mediterranean Sea, including its adjunct seas, and in the area of Atlantic from Norway to Angola. During the year it spawns between spring and autumn, with two spawning peaks (BAUCHOT \& HUREAU, 1986).

Majority of commercially important fish species, among which the above-mentioned ones, are shared between the Adriatic countries. Studied fish stocks, except Common pandora, therefore are assessed and managed at the regional level (GSA 17, GSA 18) by STECF and GFCM. Their biomass levels as well as their catches had fluctuated over the last two decades. Those fish abundance alternations observed in Adriatic and worldwide might be linked to many anthropogenic (JENNINGS et al., 2001) and environmental factors (GRBEC et al., 2015; BROSSET et al., 2017). In order to comprehend those oscillations and to insure sustainable fisheries, scientists are rebuilding their knowledge concerning fish species biology, ecology and marine ecosystem in general. Since studied species are ecologically and economically important it is not possible to make comprehensive review covering all the issues and topics within one review paper. Hence, the main goal of this review was to investigate potential spawning and nursery grounds specified in the last two decades (since no literature review was given in the period) for herein reviewed Adriatic fish species.

The spawning and nursery grounds are essential areas where survival of early fish life stages is the most likely to occur. Selection of such geographical area is complex task that depends on numerous constraints referring to ecology and evolution (CIANNELLI et al., 2014). Bearing in mind that climatic conditions have changed during the last couple of decades in the Adriatic (GRBEC et al., 2015, 2018; ZVERYAEV \& HANNACHI, 2017) devotion of the studied species to the same geographical area for spawning it was interrogative. This kind of investigation should also point out the possible gaps, changes and limitations in existing knowledge regarding the distribution of their early life stages in the Adriatic Sea. Gathered information might bring us closer to better understanding of the success and output of spawning at the end resulting with recruitment, that largely define renewal of fish population.

\section{Study area}

The Adriatic Sea (Fig. 1) is the northernmost semi-enclosed basin in the Mediterranean with a cyclonic circulation. The cyclonic circulation pathway is caused by the estuarine conditions, which are regulated by the northern Adriatic rivers (CUSHMAN-ROISIN et al., 2001). Therefore, 


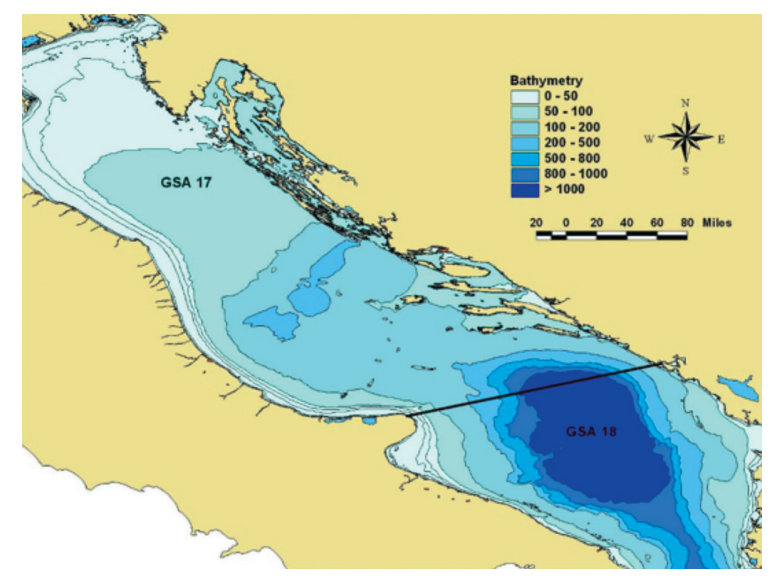

Fig. 1. Bathymetric map of Adriatic Sea with marked separation between GSA 17 and GSA 18

along the western side of Adriatic out flowing West Adriatic Current is noticed, while on its eastern side East Adriatic Current (ORLIĆ et al., 2007 ) is bringing Levantine Intermediate Water (ROBINSON et al., 1992; MALANOTTE-RIZZOLI et al., 1997) from the Ionian and Levantine Seas. From time to time Levantine Intermediate Water can flood the Adriatic in so-called ingression years (BULJAN, 1953) when increase in salinity, temperature and nutrients in intermediate layers are detected (BULJAN \& ZORE-ARMANDA, 1979; TZIPERMAN \& MALANOTTE-RIZZOLI, 1991; VILIBIĆ \& ORLIĆ, 2001, 2002). In the Adriatic during the winter water column is homogenized due to substantial wind-mixing and winter surface cooling, while in summer, when wind mixing is very mild, Adriatic waters become highly stratified (BULJAN \& ZORE-ARMANDA, 1976). This area due to its geographical position, previously described circulation pattern and the fact that is oligotrophic (MOZETIČ et al., 2010; KOVAČ et al., 2018) is recognized as climate sensitive one. From 1950 to 2010 two climatic turning points (around 1987 and 1998) that separate relatively stable climate regimes were detected (GRBEC et al., 2015).

\section{Spawning and nursery grounds}

\section{Sardine, Sardina pilchardus}

Sardine specimens inhabiting the Adriatic Sea tend to spawn from the beginning of the
October till the end of April and this has not changed over the last two or more decades (MORELLO \& ARNERI, 2009; MUSTAĆ \& SINOVČIĆ, 2009; PEŠIĆ et al., 2010; ZORICA et al., 2016, 2017). The peak of sardine spawning, which mostly depends on environmental parameters such as temperature $\left(11-16^{\circ} \mathrm{C}\right.$; MORELLO \& ARNERI, 2009), occurs between November and February (SINOVČIĆ et al., 2008; PEŠIĆ et al., 2010; PEŠIĆ, 2011; ZORICA et al., 2017; 2019). As many other clupeid species, sardine is a "batch" spawner with indeterminate fecundity which individuals reached their sexual maturity at $8.0 \mathrm{~cm}$ of total length (SINOVČIĆ et al., 2003). During the reviewed period few studies on early life stages were done and their results are presented in Table 1. Bearing in mind peaking of sardine spawning, it was expected and also confirmed that the largest number of eggs and larvae were found during the colder part of the year (Table 1). Although sardine early life stages were found along the whole eastern part some areas with their higher abundances were noted and defined as most probable sardine spawning grounds like Kvarner area, area beyond the Island of Dugi otok, outer part of mid-Dalmatian islands and area of Boka Kotorska Bay (MANDIĆ, 2011, ZORICA et al., 2015; 2019).

Those areas were in accordance with results published in review by MORELLO \& ARNERI (2009) except the area of Boka Kotorska Bay. Namely, in the Boka Kotorska Bay, only one ichthyoplankton survey was done in the colder part of the year (December 2006) and intense sardine spawning was noted due to stable environmental conditions, and it might be considered as possible spawning ground that should be further investigated so that it can be verified or not in future. Since sardine eggs and larvae appeared in almost the same areas, at least on the eastern Adriatic, those areas could also be considered as nursery areas. Beside those nursery areas detected via ichthyoplankton sampling, SINOVČIĆ et al. (2009) defined Krka river estuary as nursery area of sardine. Regarding the western Adriatic in the recent paper given by SCIASCIA et al. (2018) as well as in paper published before (MORELLO \& ARNERI 2009; BORME et al., 2013; CARPI et al., 
Table 1. Sardine, Sardina pilchardus - overview of early life stages abundances in the Adriatic Sea over the last two decades

\begin{tabular}{|c|c|c|c|c|c|c|}
\hline \multirow[t]{2}{*}{ Author } & \multirow[t]{2}{*}{ Geographical area } & \multirow[t]{2}{*}{ Month/Year } & \multicolumn{2}{|c|}{$\begin{array}{l}\text { Eggs abundance } \\
\left(\mathrm{egg} / \mathrm{m}^{2}\right)\end{array}$} & \multicolumn{2}{|c|}{$\begin{array}{l}\text { Larvae abundance } \\
\left({\left.\text { larvae } / m^{2}\right)}^{2}\right.\end{array}$} \\
\hline & & & Range & Mean & Range & Mean \\
\hline \multirow[t]{4}{*}{ MANDIĆ (2011) } & $\begin{array}{l}\text { Boko Kotorska Bay, } \\
\text { eastern Adriatic }\end{array}$ & December/2006 & $\begin{array}{l}11.9- \\
158.4\end{array}$ & 59.60 & - & 40.00 \\
\hline & & April/2007 & $3.9-29.4$ & 10.05 & - & - \\
\hline & & April/2008 & $3.2-13.3$ & 8.10 & - & - \\
\hline & & January/2009 & $4.0-4.0$ & 4.00 & - & 16.00 \\
\hline BORME et al. (2013) & $\begin{array}{l}\text { Gulf of Manfredonia, } \\
\text { western Adriatic }\end{array}$ & February/2008 & - & - & $27-35^{*}$ & - \\
\hline ZORICA et al. (2015) & $\begin{array}{l}\text { Eastern Adriatic } \\
(\text { Croatia })\end{array}$ & January/2012 & $4.0-396.0$ & 57.80 & $4.0-108.0$ & 28.41 \\
\hline \multirow[t]{7}{*}{ HORVAT (2017) } & $\begin{array}{l}\text { Northern eastern } \\
\text { Adriatic (Slovenia) }\end{array}$ & September/2014 & - & 11.00 & - & - \\
\hline & & November/2014 & - & 19.00 & - & - \\
\hline & & December/2014 & - & 7.00 & - & - \\
\hline & & January/2015 & - & 6.00 & - & - \\
\hline & & February/2015 & - & 8.00 & - & - \\
\hline & & $\operatorname{March} / 2015$ & - & 4.00 & - & - \\
\hline & & April/2015 & - & 4.00 & - & - \\
\hline ZORICA et al. (2019) & $\begin{array}{l}\text { Middle eastern } \\
\text { Adriatic (Croatia) }\end{array}$ & November/2017 & $\begin{array}{l}12.0- \\
240.0\end{array}$ & 56.22 & $4.0-56.0$ & 19.20 \\
\hline
\end{tabular}

*given values are the numbers of collected sardine larvae

2017) the Gulf of Manfredonia was defined as a sardine nursery area. According to reported data sardine larvae and juveniles are transported by the southward boundary current WAC (Western Adriatic Current) from its spawning ground into the Gulf of Manfredonia (SCIASCIA et al., 2018). Previously mentioned authors in their papers indicate that sardine spawning grounds on the western Adriatic part are located north (Gulf of Trieste, Po River Delta, northern Italian coastline, the central Italian coastline, the northern Gargano) of the above-mentioned nursery ground.

\section{Anchovy, Engraulis encrasicolus}

Anchovy has an extended spawning season that starts at the end of March and lasts until October with reproductive activity peaking from April to July noted by SINOVČIĆ \& ZORICA (2006), ĐUROVIĆ (2012), ZORICA et al. (2013) and ĐUROVIĆ et al. (2018). The total length at which $50 \%$ of anchovy population attain maturity ranged from $7.5 \mathrm{~cm}$ to $9.0 \mathrm{~cm}$ of total length (SINOVČIĆ \& ZORICA, 2006; MORELLO \& ARNERI 2009), while in the area of Boka Kotorska Bay it was calculated as $9.28 \mathrm{~cm}$ for females and $9.02 \mathrm{~cm}$ for males (MANDIĆ et al., 2015). Histological examination of anchovy gonad tissue confirmed that this species is a batch spawner with asynchronous oocyte development and indetermined fecundity (RADONIĆ et al., 2018; ĐUROVIĆ et al., 2018). Within each batch Adriatic anchovy released approximately 3336.8 to 19875.1 eggs/g (MANDIĆ et al., 2015; RADONIĆ et al., 2018). The value of batch fecundity is known to vary annually and it is affected mostly by the different environmental conditions (temperature, available food) (MURUA et al., 2003; GANIAS, 2009).

During the last two decades several scientific surveys were done during the warmer part of the year (July - September, Table 2). Since the 
ZORICA et al: A review of reproduction biology and spawning/ nursery grounds of the most important Adriatic ....93

Table 2. Anchovy, Engrulis encrasicolus - overview of early life stages abundances in the Adriatic Sea over the last two decades

\begin{tabular}{|c|c|c|c|c|c|c|}
\hline \multirow{2}{*}{ Author } & \multirow{2}{*}{ Geographical area } & \multirow{2}{*}{ Month/Year } & \multicolumn{2}{|c|}{ Eggs abundance $\left(\mathrm{egg} / \mathrm{m}^{2}\right)$} & \multicolumn{2}{|c|}{ Larvae abundance (larvae $/ \mathrm{m}^{2}$ ) } \\
\hline & & & Range & Mean & Range & Mean \\
\hline \multirow[t]{5}{*}{$\begin{array}{l}\text { MANDIĆ } \\
(2011 ; 2015)\end{array}$} & $\begin{array}{l}\text { Boko Kotorska } \\
\text { Bay, eastern } \\
\text { Adriatic } \\
\end{array}$ & July/2006 & $25.59-565.05$ & 163.35 & $4.6-97.9$ & \\
\hline & & April/2007 & $10.39-823.11$ & 131.37 & $1.07-145.2$ & \\
\hline & & August/2007 & $13.72-581.11$ & 99.19 & $5.52-57.86$ & \\
\hline & & April/2008 & $9.07-267.90$ & 60.37 & & \\
\hline & & July/2008 & $23.84-1039.17$ & 293.52 & & \\
\hline $\begin{array}{l}\text { TIRELLI et al. } \\
\text { (2013) }\end{array}$ & $\begin{array}{l}\text { Gulf of Trieste- } \\
\text { Gargano } \\
\text { Promontory, } \\
\text { western Adriatic }\end{array}$ & September/2011 & $0-477.75$ & & & \\
\hline $\begin{array}{l}\text { ZORICA et al. } \\
(2015)\end{array}$ & $\begin{array}{l}\text { Eastern Adriatic } \\
\text { (Croatia) }\end{array}$ & July/2013 & $4.0-800.0$ & 145.26 & $8.0-952.0$ & 115.11 \\
\hline $\begin{array}{l}\text { HORVAT } \\
(2017)\end{array}$ & $\begin{array}{l}\text { Northern } \\
\text { eastern Adriatic } \\
\text { (Slovenia) }\end{array}$ & $\begin{array}{l}\text { August/2014 - } \\
\text { July/2015 }\end{array}$ & $8.0-629.0$ & & & \\
\hline \multirow[t]{4}{*}{$\begin{array}{l}\text { MALAVOLTI } \\
\text { et al. }(2018)\end{array}$} & $\begin{array}{l}\text { western } \\
\text { continental shelf } \\
\text { of Adriatic (GSA } \\
18) \\
\end{array}$ & June - July/2012 & & $39.49^{*}$ & & $52.78 *$ \\
\hline & & June - July/2013 & & $26.99 *$ & & $40.04 *$ \\
\hline & & June - July/2014 & & $20.51^{*}$ & & $24.47^{*}$ \\
\hline & & June - July/2015 & & $25.61^{*}$ & & $44.66^{*}$ \\
\hline $\begin{array}{l}\text { ZORICA et al. } \\
(2018)\end{array}$ & $\begin{array}{l}\text { Whole eastern } \\
\text { Adriatic }\end{array}$ & July/2013 & $2.61-1040.24$ & $25.43 *$ & $2.73-611.14$ & $17.07^{*}$ \\
\hline $\begin{array}{l}\text { ZORICA et al. } \\
(2019)\end{array}$ & $\begin{array}{l}\text { Middle eastern } \\
\text { Adriatic (Croatia) }\end{array}$ & July/2017 & $8.0-140.0$ & 37.18 & $4.0-136.0$ & 44.88 \\
\hline $\begin{array}{l}\text { ZORICA et al. } \\
\text { (2019) }\end{array}$ & $\begin{array}{l}\text { Eastern Adriatic } \\
\text { (Croatia) }\end{array}$ & July/2018 & $4.0-228.0$ & $34.56^{*}$ & $4.0-60.0$ & $10.58 *$ \\
\hline
\end{tabular}

*given values are the numbers of collected sardine larva

time of those surveys overlapped with anchovy spawning from collected ichthyoplankton samples scientists managed to isolate, count and define abundances of anchovy early life stages as it is shown in Table 2. Highest abundances of anchovy eggs/ larvae were noted during the July as it was expected considering the fact that at that month Adriatic anchovy reach its spawning peak. In the whole Adriatic, areas with the higher abundances of its early life stages are mostly placed northern, precisely in GSA 17 - the Gulf of Trieste (TIRELLI et al., 2013, HORVAT, 2017), the Gulf of Venice (TIRELLI et al.,
2013), Kvarnerić area, area beyond the Island of Dugi otok, outer part of mid-Dalmatian islands (ZORICA et al., 2015, 2018, 2019) and Zrmanja River estuary (SINOVČIĆ, 2004, SINOVČIĆ \& ZORICA, 2006). Those anchovies spawning and/or nursery areas were previously characterised as nutrient-enriched areas due to the river inputs or upwelling (MARASOVIĆ et al., 1988; REVELANTE \& GLIMARTIN, 1992; GAČIĆ et al., 1997; MAURI \& PAULAIN, 2001; KRŠINIĆ, 2010), hence occurrence of anchovy early life stages were expected there. As far as the southern Adriatic is concerned, somewhat lower values of anchovy eggs/larvae 
abundance were noted in the last two decades (ZORICA et al., 2019) as well as before (MORELLO \& ARNERI, 2009), few favourable areas for early life stages were distinguished - the Gulf of Manfredonia (MALAVOLTI et al., 2018), area of Boka Kotorska Bay (MANDIĆ, 2011; MANDIĆ et al., 2011, 2013, 2015; 2017; ZORICA et al., 2019) and the area in front of the northern Albania coastline (ZORICA et al., 2019).

According to ZORICA et al. (2019) findings it seems that anchovy tend to shift its spawning centres during its protracted spawning linked to achieving favourable environmental conditions. Precisely, it seems that Adriatic anchovy population firstly starts to spawn in northern and shallower part of Adriatic, where favourable conditions are reached first, and as summer progress anchovy shift it spawning towards the southern areas. Furthermore, over the last two decades' analysis of ichthyoplankton samples reveal that anchovy for its spawning in the area of middle and southern Adriatic preferred the areas with sea depths from $70 \mathrm{~m}$ to $120 \mathrm{~m}$ (MALAVOLTI et al., 2018; ZORICA et al., 2019).

\section{European hake, Merluccius merluccius}

According to monthly changes of maturity stages, gonadosomatic indices and gonad weight of European hake from the Adriatic Sea it is obvious that this species spawns all year round (VRGOČ et al., 2004; 2005) and reaches its first maturity at $20.5 \mathrm{~cm}$ (females) $/ 22.5 \mathrm{~cm}$ (males) (VRGOČ et al., 2005). This protracted spawning period has been one of the known characteristics of genus Merluccius since it was reported previously for M. merluccius (RECASENS et al., 2008), M. capensis (KAINGE et al., 2007) and M. hubbsi (MACCHI et al., 2004).

Even though all reproductive traits of this species oscillated over the years in this area somewhat higher spawning activity was reported between May and October (VRGOČ et al., 2004; 2005). Due to that spawning activity recruitment peak in winter period was noted. Beside this one another recruitment peak was reported in summer period that indicated spawning activity during the winter (VRGOČ et al., ibid). Essen- tial habitats (spawning and nursery grounds) for this commercially highly important species were detected regarding the systematic scientific research done throughout MEDITS surveys in Adriatic Sea since 1996. According to data collected through that surveys and published by PICCINETTI et al. (2012) the most important spawning and nursery area of hake was the area of open middle Adriatic. Considering the importance of central Adriatic in the repopulation of hake population, as well as of Norway lobster population, General Fisheries Commission of Mediterranean established in 2017 a Fisheries Restricted Area in the Jabuka pit (GFCM, 2017). Apart from Jabuka/Pomo pit and middle Adriatic area few smaller spawning areas were located in channel areas of the north eastern Adriatic including the deepest parts of Kvarneric and part of Velebit channel (VRGOČ et al., 2004; 2005; PICCINETTI et al., 2012), while on the western side nursery area off the Gargano peninsula in the South Adriatic Sea was identified by CARLUCCI et al. (2009).

\section{Common pandora, Pagellus erythrinus}

Over the last two decades' studies concerning this species biology, particularly reproduction biology, are scarce. According to studies done in framework of Project DemMon (Croatian Fishing ground, summer 2002 - spring 2003) VRGOČ et al. (2004) confirmed common pandora as protogynous hermaphrodite, which females change sex at the size classes $17-20 \mathrm{~cm}$ of total length. Same authors reported based to its gonad macroscopic stages and the GSI value, that this species spawned from April to September (peak from May to August), although female specimens in stage of spawning (ripe gonads) were found almost during the whole year (expect December and January; VRGOČ et al., 2004). Observed specimens within the study area reached its first sexual maturity at $12.5 \mathrm{~cm}$ (VRGOČ, 2000). According to results of MEDITS surveys PICCINETTI et al. (2012), define that common pandora juveniles preferred shallow coastal waters as they were found mainly along western Istrian Coast, in channel areas of central Adriatic and estuary of Neretva River. Besides, those areas, 
DULČIĆ et al. (2002) reported the area of Šibenik (middle Adriatic - in the vicinity of Lake Vran and River Krka estuary) as nursery area of many species among which were also noted juveniles of common pandora. COLLOCA et al. (2015) analysed the European Union Mediterranean waters using time series of bottom trawl survey data for the period 1994-2010 and confirmed central/ northern Adriatic as nursery area. They also noted somewhat larger nursery area spreading from the north-eastern Italian coast to the eastern coast of Istria (Croatia) at a depth of 5-20 m and smaller ones near Neretva River estuary. As far as southern Adriatic concerned few smaller areas among which northern Albanian coast was distinguished (COLLOCA et al. 2015).

\section{CONCLUSIONS}

Envisaging above mentioned and previously published, it is obvious that Adriatic Sea and its resources were and still are in the focus of many scientific investigations. Despite scientific effort all biological and ecological aspects of many exploited Adriatic fishes are still unknown or scarcely investigated. This review study of reproductive biology that included examination of spawning and nursery areas for four economically and ecologically important fish species over the time period of last two decades pointed out area of open middle Adriatic as small pelagic fish species spawning and nursery ground and the area of European hake successful recruitment. Area of shallow northern Adriatic was highlighted as area significant for early life stages of anchovy and common pandora, while on the southern part of Adriatic Gulf of Manfredonia distinguished itself as by far most important nursery area for both small pelagic fish species and European hake.

Nevertheless, all estuary areas (rivers Po, Zrmanja, Krka, Neretva, Bojana) or the upwelling areas (middle Adriatic) were also desirable for spawning or nursing of investigated fish species. Throughout this work it was evident that elemental reproductive biological parameters for two investigated demersal fish species are lacking, so this is something that should be covered in future. Ichthyoplanktonic survey are mainly done during the summer months due to better weather conditions, so, in future some effort should be invested in order to provide better information for species that spawn in colder part of the year such as sardine. All of this is needed in order to define, comprehend and protect ecologically sensitive areas of commercially exploited species that should become a baseline for improved management regulations in achieving optimal conservation of those renewable resources.

\section{ACKNOWLEDGEMENTS}

This study was supported throughout the project "Exploration of ecologically sensitive areas with special emphasis on growth, development and protection of commercially important maritime organisms (ESAmar)" founded by Croatian Science Foundation. Thanks to the anonymous reviewers for their useful comments on the manuscript.

\section{REFERENCES}

BAUChOT, M. L. \& J. C. HUREAU. 1986. Sparidae. In: WHITEHEAD, P. J. P., BAUCHOT, M. L., HUREAU, J. C., NIELSEN, J., TORTONESE, E. (Editors), Fishes of the north-eastern Atlantic and the Mediterranean. Paris, UNESCO, p. 883-907.

BORME, D., V. TIRELLI \& I. PALOMERA. 2013. Feeding habits of European pilchard late larvae in a nursery area in the Adriatic Sea. J. Sea Res., 78: 8-17.
BROSSET, P., J.M .FROMENTIN, E. VAN BEVEREN, J. LlORET, V. MARQUES, G. BASILONE, A. BONANNO, P. CARPI, A. DE FELICE, F. DONATO, R. FERRERI, A. GIRÁLDEZ, A. GÜCÜ, M. IGLESIAS, V. ČIKEŠ KEČ, I. LEONORI, I.. PALOMERA, S. SOMARAKIS, V. TICINA, P. TORRES, A. VENTERO, B. ZORICA, F. MENARD, \& C. SARAUX. 2017. Spatio-temporal patterns and environmental controls of small pelagic fish body condition from contrasted Mediter- 
ranean areas. Prog. Oceanogr.,151: 149-162. BULJAN, M. 1953. Fluctuations of salinity in the Adriatic. Reports Exped. 'Hvar', 2: 64 pp. BULJAN, M. \& M. ZORE-ARMANDA. 1976. Oceanographic properties of the Adriatic Sea. Oceanogr. Mar. Biol. Ann. Rev., 14:11-98.

CARLUCCI, R., G. LEMBO, P. MAIORANO, F. CAPEZZUTO, C. A. MARANO, L. SION, M. T. SPEDICATO,. N. UNGARO, A. TURSI, \& G. D'ONGHIA. 2009. Nursery areas of red mullet (Mullus barbatus), hake (Merluccius merluccius) and deep-water rose shrimp (Parapenaeus longirostris) in the Eastern-Central Mediterranean Sea. Estuar. Coast. Shelf Sci., 83: 529-538. CARPI, P., E. B. MORELLO, A. URIARTE, M. PANFILI, B. ROEL, A. SANTOJANNI, F. DONATO, E. ARNERI, \& H. EMORY ANDERSON. 2017. Impact of the fishery for late-larval European sardine (Sardina pilchardus) on the adult stock in the Adriatic Sea, ICES J. Mar.Sci., 74: 728-740.

CIANNELLI, L., K. BAILEY \& E. M. OLSEN. 2014. Evolutionary and ecological constraints of fish spawning habitats. ICES J. Mar. Sci., 72: 285-296.

COLLOCA, F., GAROFALO, G., BITETTO, I., FACCHINI, M. T., GRATI, F., MARTIRADONNA, A., et al. 2015. The Seascape of Demersal Fish Nursery Areas in the North Mediterranean Sea, a First Step Towards the Implementation of Spatial Planning for Trawl Fisheries. PLoS ONE, 10(3): e0119590. doi:10.1371/ journal. pone. 0119590

CUSHMAN-ROISIN, B., GAČIĆ, M., POULAIN, P.-M. \& A. ARTEGIANI. 2001. Physical Oceanography of the Adriatic Sea.Dordrecht: Kluwer Academic Publishers, 304 pp.

DULČIĆ, J., MATIĆ, S. \& M. KRALJEVIĆ. 2002. Shallow coves as nurseries for non-resident fish: a case study in the eastern middle Adriatic. J. Mar. Biol. Ass. U.K., 82: 991-993.

ĐUROVIĆ, M. 2012. Ekološka istraživanja juvenilnog inćuna, Engraulis encrasicolus (Linnaeus, 1758), u Kotorskom zalivu.PhD Thesis, Univerzitet u Beogradu, Biološki Fakultet, Beograd, 129 p.

ĐUROVIĆ, M., A. JOKSIMOVIĆ, A. PEŠIĆ, O. MARKOVIĆ, S. REGNER, M. MANDIĆ \& Z. IKICA. 2018. Reproductive pattern of the anchovy, Engraulis encrasicolus (Linnaeus,
1758), in the Boka Kotorska Bay (Montenegro, southern Adriatic Sea). Acta Adriat., 59(2): $173-184$

GAČIĆ, M., MARULLO, S., SANTOLERI, R. \& A. BERGAMASCO. 1997. Analysis of the seasonal and interannual variability of the sea surface temperature field in the Adriatic Sea from AVHRR data (1984-1992). J. Geophys. Res., 102: 2937-2946

GANIAS, K. 2009. Linking sardine spawning dynamics to environmental variability. Estuar. Coast. Shelf Sci., 84:402-408

GRBEC, B., M. MOROVIĆ, F. MATIĆ, Ž. NINČEVIĆ GLADAN, I. MARASOVIĆ, O. VIDJAK, N. BOJANIĆ, V. ČIKEŠ KEČ, B. ZORICA, G. KUŠPILIĆ \& S. MATIĆ-SKOKO. 2014. Climate regime shifts and multi-decadal variability of the Adriatic Sea pelagic ecosystem. Acta Adriat,, 55(2): 117 - 126.

GFCM. 2007. Recommendation GFCM/41/2017/3 on the establishment of a fisheries restricted area in the Jabuka/Pomo Pit in the Adriatic Sea, p. 7.

HORVAT, E. 2017. Časovno in prostorsko pojavljanje iker sardele (Sardina pilchardus) in sardona (Engraulis encrasicolus) v Slovenskem morju. Mag. delo. Ljubljana, Univ. v Ljubljani, Biotehniška fakulteta, Študij ekologije in biodiverzitete, pp. 98.

JARDAS, I. 1996. The Adriatic ichthyofaunal (in Croatian). Školska knjiga d. d., Zagreb, p. 543.

JENNINGS, S., T.A. DINMORE, D.E. DUPLISEA, K.J. WARR \& J. E. LANCASTER. 2001. Trawling disturbance can modify benthic production processes. J. Anim. Ecol., 70: 459-475.

JUKIĆ, S. \& C. PICCINETTI. 1987. Biological and economic aspects of mesh size regulationin the multispecies demersal fishery of the Adriatic Sea. Acta Adriat., 28:199-219.

KAINGE, P., O.S, KJESBU, A. THORSEN \& A.G. SALVANES. 2007. Merluccius capensis spawn in Namibian waters, but do M. paradoxus? Afr. J. Mar. Sci., 29(3): 379-392.

KARLOVAC, J. 1965. Contibution a la connaissance de l'ecologie du merlu Merluccius merluccius L. dans le stade planctonique de sa vie en Adriatique. Rapports et Procès Verbaux Commission Internationale Exploration 
Scientifique Mer Méditerranée, 18:333-339. KOVAĆ, Ž., T. PLATT, Ž. NINČEVIĆ GLADAN, M. MOROVIĆ, S. SATHYENDRANATH, R. DAITSOS, B. GRBEC, F. MATIĆ \& J. VEŽA. 2018. A 55-Year Time Series Station for Primary Production in the Adriatic Sea: Data Correction, Extraction of Photosynthesis Parameters and Regime Shifts. Remote Sens. doi:10.3390/ rs 10091460

KRŠINIĆ, F. 2010. Tintinnids (Tintinnida, Choreotrichia, Ciliata) in the Adriatic Sea, Mediterranean. Acta Adriat., Part II - Ecology, p 114.

MACCHI, G.J., PÁJARO, M. \& M. EHRLICH. 2004. Seasonal egg production pattern of the Patagonian stock of Argentine hake (Merluccius hubbsi). Fish. Res., 67: 25-38.

MALANOTTE-RIZZOLI, P., B.B. MANCA \& M.R. D'ALCALA et al. 1997. A synthesis of $\mathrm{t} h \mathrm{e}$ Ionian Sea hydrography, circulation and water mass pathways during POEM-Phase I. Prog. Oceanogr., 39:153-204.

MALAVOLTI, S., A. DE FELICE, I. COSTANTINI, I. BIAGOTTI, G. CANDUCI, F. GRILLI, M. MARINI, V. TIRELLI, D. BORME, V. CAPUTO BARUCCHI \& I. LEONORI. 2018. Distribution of Engraulis encrasicolus eggs and larvae in relation to coastal oceanographic conditions (the Southwestern Adriatic Sea case study). Mediterr. Mar. Sci., 19: 180-192.

MANDIĆ, M. 2011. Seasonal Aspects of Ichthyoplankton Diversity in the Boka Kotorska Bay (PhD Thesis). University of Belgrade. $169 \mathrm{p}$. MANDIĆ, M., S. REGNER, J. KRPO-ĆETKOVIĆ \& A. JOKSIMOVIĆ. 2011. Unusual occurrence of anchovy (Engraulis encrasicolus Linnaeus, 1758) eggs in December 2006 in Boka Kotorska Bay (Adriatic Sea). Acta Adriat., 53(1): 133-137.

MANDIĆ, M., M. ĐUROVIĆ, A. PEŠIĆ, A. JOKSIMOVIĆ \& S. REGNER. 2013. Boka Kotorska Bay spawning and nursery area for pelagic fish species. Stud. Mar., 26 (1): 33-46.

MANDIĆ, M., S. REGNER, M. ĐUROVIĆ, A. JOKSIMOVIĆ, A. PEŠIĆ \& J. KRPO-ĆETKOVIĆ. 2015. Distribution and abundance of eggs and estimation of spawning stock biomass of anchovy, Engraulis encrasicolus (Linnaeus, 1758), in the South-eastern Adriatic Sea. J. Mar. Biol. Assoc. U.K., 1-9.
MANDIĆ, M.,A. PEŠÍ́, M. ĐUROVIĆ, A. JOKSIMOVIĆ \& S. REGNER. 2017. Composition and distribution of ichthyoplankton in the Boka Kotorska Bay. In (eds.) The Boka Kotorska Bay Environment. Hdb Env Chem, Springer International Publishing Switzerland, 54: pp. 295-312.

MARASOVIĆ, I., T. PUCHER-PETKOVIC \& V. ALEGRIA-HERNANDEZ. 1988.Phytoplankton productivity of the Adriatic Sea in relation to pelagic fisheries. Bilješke - Notes, 72: 1-8.

MAURI, E. \& P. M. POULAIN. 2001. Northern Adriatic Sea surface circulation and temperature/ pigment fields in September and October 1997. J. Mar. Syst., 29: 51-67.

MORELLO, B. E. \& E. ARNERI. 2009. Anchovy and sardine in the Adriatic Sea an ecological review. Oceanography and Marine Biology: An Annual Review, 47: 209-256.

MOZETIČ, P., C. SOLIDORO, G. COSSARINI, G. SOCAL, R. PRECALI, J., FRANCÉ, F.BIANCHI, C. DE VITTOR, N. SMODLAKA \& S.F. UMANI. 2010. Recent Trends Towards Oligotrophication of the Northern Adriatic: Evidence from Chlorophyll a Time Series. Estuar. Coast., 33: 362-375.

MURUA, H., G. KRAUS, F. SABORIDO-REY, P. R. WITTHAMES, A. THORSEN \& S. JUNQUERA. 2003. Procedures to estimate fecundity of marine fish species in relation to their reproductive strategy. J. Northwest Atl. Fish. Sci., 33: 33-54.

MUSTAĆ, B. \& G. SINOVČIĆ. 2009. Comparison of mesenteric and tissue fat content in relation to sexual cycle of the sardine, Sardina pilchardus (Walb., 1792), in the eastern Middle Adriatic fishery grounds (Croatia). J. Appl. Ichthyol., 25: 595-599.

MURUA, H. \& F. SABORIDO-REY. 2003. Female reproductive strategies of marine fish species of the North Atlantic. J. Northwest Atl. Fish. Sci., 33:23-31.

ORLIĆ, M., V. DADIĆ, B. GRBEC, N. LEDER, A. MARKI, F. MATIĆ, H. MIHANOVIĆ, G. BEG PAKLAR, M. PASARIĆ, Z. PASARIĆ \& I. VILIBIĆ. 2007. Wintertime buoyancy forcing, changing seawater properties and two different circulation systems produced in the Adriatic. Journal of Geophysical Research - Oceans 112, C03. doi:10.1029/2005JC00327. 
PEŠIĆ, A. 2011. Ribarstveno - biološka istraživanja juvenilne srdele (Sardina pilchardus Walbaum 1792.) u Kotorskom zalivu (Fisheries and biological researhes of juvenile sardine (Sardina pilchardus Walbaum 1792) in Kotor Bay). PhD Thesis, University of Belgrade, Biological Faculty, Belgrade, 118 p.

PEŠIĆ, A., M. ĐUROVIĆ, A. JOKSIMOVIĆ, S. REGNER, P. SIMONOVIĆ, \& B. GLAMUZINA. 2010. Some reproductive patterns of the sardine, Sardina pilchardus (Walb, 1792), in Boka Kotorska Bay (Montenegro, southern Adriatic Sea). Acta Adriat., 51(2): 159 - 168

PICCINETTI, C., N. VRGOČ, B. MARČETA \& C. MANFREDI. 2012. Recent state of demersal resources in the Adriatic Sea. Acta Adriat, Monograph Ser. No. 5, 220 p.

RADONIĆ, I., B. ZORICA, V. ČIKEŠ KEČ, V. VULETIN \&D. EZGETA-BALIĆ. 2018. Preliminarna procjena frekvencije mrijesta i 'batch' fekunditeta inćuna Engraulis encrasicolus (Linnaeus, 1758) u Jadranskom moru. 13. HRVATSKI BIOLOŠKI KONGRES s međunarodnim sudjelovanjem, Zbornik sažetaka. 249-250

RECASENS, L., V. CHIERICONI \& P. BELCARI. 2008. Spawning pattern and batch fecundity of the European hake (Merluccius merluccius (Linnaeus, 1758)) in the western Mediterranean. Sci. Mar., 72(4): 721-732.

RELINI G., J. BERTRAND \& A. ZAMBONI. 1999. Synthesis of the knowledge on bottom fishery resources in central Mediterranean (Italy and Corsica). Biol. Mar. Medit., 6 (suppl. 1): 642-648.

REVELANTE, N. \& M. GLIMARTIN. 1992. The lateral advection of particulare organic matter from the Po delta region during summer stratification, and its implications for the northern Adriatic. Estuar. Coast. Shelf Sci., 35: $191-212$

ROBINSON, A.R., P. MALANOTTE-RIZZOLI, A. HECHT, A. MICHELATO, W. ROETHER, A. THEOCHARIS, Ü. ÜNLÜATA, , N. PINARDI, A. ARTEGIANI, A. BERGAMASCO, J. BISHOP, S. BRENNER, S. CHRISTIANIDIS, M. GAČIĆ, D. GEORGOPOULOS, M. GOLNARAGHI, M. HAUSMANN, H.G. JUNGHAUS, A. LASCARATOS, M.A. LATIF, W.G. LESLIE, C.J. LOZANO, T. OGUZ, E. ÖSZOY, E. PAPAGEORGIOU, E. PASCHINI, Z.
ROZENTROUB, E. SANSONE, P. SCARAZZATO, R. SCHLITZER, G.C. SPEZIE, E.TZIPERMAN, G. ZODIATIS, L. ATHANASSIADOU, M. GERGES \& M. OSMAN. 1992. General circulation of the Eastern Mediterranean. Earth-Science Reviews, 32: 285-309.

SCIASCIA, R., M. BERTA, D. F. CARLSON, A. GRIFFA, M. PANFILI, M. LA MESA, L. CORGNATI, C. MANTOVANI, E. DOMENELLA, E. FREDJ, M. G. MAGALDI, R. D’ADAMO, G. PAZIENZA, E. ZAMBIANCHI \& P.M. POULAIN. 2018. Linking sardine recruitment in coastal areas to ocean currents using surface drifters and HF radar: a case study in the Gulf of Manfredonia, Adriatic Sea. Ocean Sci., 14: 1461-1482.

SINOVČIĆ, G. 2004. Growth and length-weight relationship of the juvenile anchovy, Engraulis encrasicolus (Linnaeus, 1758), in the nursery ground (Zrmanja River estuary- eastern Adriatic Sea). J. Appl. Ichthyol., 20 (1): 79-80.

SINOVČIĆ, G. \& B. ZORICA. 2006. Reproductive cycle and minimal length at sexual maturity of Engraulis encrasicolus (L.) in the Zrmanja River estuary (Adriatic Sea, Croatia). Estuar. Coast. Shelf Sci., 69 (3-4): 439-448.

SINOVČIĆ, G., V. ČIKEŠ KEČ \& B. ZORICA. 2008. Population structure, size at maturity and condition of sardine, Sardina pilchardus (Walb., 1792), in the nursery ground of the eastern Adriatic Sea (Krka River estuary, Croatia). Estuar. Coast. Shelf Sci., 76(4): 739-744.

SINOVČIĆ, G., B. ZORICA, V. ČIKEŠ KEČ \& B. MUSTAĆ. 2009. Inter-annual fluctuations of the population structure, condition, lengthweight relationship and abundance of sardine, Sardina pilchardus (Walb., 1792), in the nursery and spawning ground (coastal and open sea waters) of the estern Adriatic Sea (Croatia). Acta Adriat., 50(1): 11-21.

SINOVČIĆ, G., B. ZORICA, M. FRANIČEVIĆ \& V. ČIKEŠ KEČ. 2003. First sexual maturity of sardine, Sardina pilchardus (Walb.) in the eastern Adriatic Sea. Period. Biol., 105(4): 401-404.

TIRELLI, V., D. BORME, T. JURETIĆ, A. DE OLAZABAL, I. BIAGIOTTI, G. CANDUCI, A. DE FELICE, F. GRILLI, M. MARINI \& I. LEONORI. 2013. Distri- 
bution of Engraulis encrasicolus eggs in the western Adriatic Sea. Poster, XXI Congresso AIOL, Lignano Sabbiadoro (UD), Poster.

TZIPERMAN, A. \& P. MALANOTTE-RIZZOLI. 1991. The climatological seasonal circulation of the Mediterranean Sea. J. Mar. Res., 49: 411-434.

UNEP-MAP-RAC/SPA. 2014. Status and Conservation of Fisheries in the Adriatic Sea. By H. Farrugio \& Alen Soldo. Draft internal report for the purposes of the Mediterranean Regional Workshop to Facilitate the Description of Ecologically or Biologically Significant Marine Areas, Malaga, Spain, 7-11 April 2014, 50 pp.

VILIBIĆ, I. \& M. ORLIĆ. 2001. Least-squares tracer analysis of water masses in the South Adriatic (1967-1990). Deep-Sea Res., 48:2297-2330.

VILIBIĆ, I. \& M. ORLIĆ. 2002. Adriatic water masses, their rates of formation and transport through the Otranto Strait. Deep-Sea Research I, 49: 1321-1340.

VRGOČ, N. 2000. Struktura i dinamika pridnenih zajednica riba Jadranskog mora (Structure and dynamics of demersal fish communities of the Adriatic Sea). PhD Thesis, University of Zagreb, Faculty of Science, 197 p.

VRGOČ, N., M. PEHARDA ULJEVIĆ, \& S. KRSTULOVIĆ ŠIFNER. 2005. Assessment of demersal fish and shellfish stocks commercially exploited in Croatia. PHARE 2005 Project: EuropeAid/123624/D/SER/HR, Final output, 172 p.

VRGOČ, N., E. ARNERI, S. JUKIĆ-PELADIĆ, S. KRSTULOVIĆ ŠIFNER, P. MANNINI, B. MARČETA, K. OSMANI, C. PICCINETTI \& N. UNGARO. 2004. Review of current knowledge on shared demersal stocks of the Adriatic Sea. FAO-MiPAF Scientific Cooperation to Support Responsible Fisheries in the Adriatic Sea. GPC/REP//ITA/TD-12. AdriaMed The. Doc., 12: $91 \mathrm{pp}$.

VRGOČ, N., S. KRSTULOVIĆ ŠIFNER, S. JUKIĆPELADIĆ, M. TONKOVIĆ, P. CETINIĆ, L. GRUBIŠIĆ, A. PALLAORO, V. DADIĆ, M. DESPALATOVIĆ \& et al. 2004. Monitoring i godpodarenje demerzalnim resursima uz istočnu obalu Jadrana, hrvatsko teritorijalno more (DemMon). Finalni izvještaj, 214 p.

WHITEHEAD, P.J.P., G.J. NELSON \& T. WONGRATANA. 1988. FAO Species Catalogue. Vol. 7. Clupeoid fishes of the world (Suborder Clupeoidei). An annotated and illustrated catalogue of the herrings, sardines, pilchards, sprats, shads, anchovies and wolf-herrings. Part 2 - Engraulidida. FAO Fish. Synop., $125,305-579$.

ZORICA, B., ANĐELIĆ, I. \& V. ČIKEŠ KEČ. 2019. Sardine (Sardina pilchardus) spawning in the light of fat content analysis. Sci. Mar., DOI: 10.3989/scimar.04898.07A

ZORICA, B., I. VILIBIĆ, V. ČIKEŠ KEČ \& J. ŠEPIĆ. 2013. Environmental conditions conducive to anchovy (Engraulis encrasicolus) spawning in the Adriatic Sea. Fish. Oceanogr., 22 (1): $32-40$.

ZORICA, B., ČIKEŠ KEČ, V., G. BRZULJA \& V. KRALJEVIĆ. 2015. Spatial distribution of sardine and anchovy early life stages along the eastern Adriatic Sea. XV European Congress of Ichthyology Abstract Book, pp.181-182.

ZORICA, B., V. ČIKEŠ KEČ, O. VIDJAK, I. MLADINEO \& D. EZGETA BALIĆ. 2016. Feeding habits and helminth parasites of sardine (S. pilchardus) and anchovy (E. encrasicolus) in the Adriatic Sea. Mediter. Mar. Sci., 17: 216-229.

ZORICA, B., V. ČIKEŠ KEČ, O. VIDJAK, V. KRALJEVIĆ \& G. BRZULJA. 2017. Seasonal pattern of population dynamic, spawning activities and diet composition of sardine (Sardina pilchardus W.) in the eastern Adriatic Sea. Turk. J. Zool., 41(5): 892-900.

ZORICA, B., V. ČIKEŠ KEČ, A. PEŠIĆ, S. GVOZDENOVIĆ, J. KOLITARI \& M. MANDIĆ. 2018. Spatiotemporal distribution of anchovy early life stages in the eastern part of the Adriatic Sea in relation to some oceanographic features. J Mar Biol Assoc U.K., https://doi.org/10.1017/S0025315418001145

ZVERYAEV, I. I. \& A. B. A. HANNACHI. 2017. Interdecadal changes in the links between Mediterranean evaporation and regional atmospheric dynamics during extended cold season. Int. J. Climatol., 37: 1322-1340. 


\title{
Pregled saznanja o reproduktivnoj biologiji i mrijestilištima/rastilištima komercijalno važnih riba u Jadranskom moru tijekom zadnja dva desetljeća
}

\author{
Barbara ZORICA, Vanja ČIKEŠ KEČ, Nedo VRGOČ, Igor ISAJLOVIĆ, \\ Corrado PICCINETTI, Milica MANDIĆ, Bojan MARČETA i Ana PEŠIĆ \\ "Kontakt e-pošta: zorica@izor.hr
}

\begin{abstract}
SAŽETAK
U novije vrijeme, unatoč dugoročnom sustavnom istraživanju ekosustava Jadranskog mora, a s obzirom da status većine obnovljivih morskih stokova nije u biološki dobrom stanju biomase, pojavila se nužnost proširenja postojeće zaštite komercijalno iskorištavanih vrsta. Kako bi se to realiziralo bilo je potrebito napraviti pregled svih znanstvenih spoznaja stečenih u posljednja dva desetljeća. Tako je u ovom preglednom radu naglasak stavljen na znanstvene činjenice vezane uz reproduktivnu biologiju kao i mrijestilišta i rastilišta četiriju ekološki i ekonomski važnih jadranskih vrsta riba - srdela Sardina pilchardus, brgljun Engraulis encrasicolus, oslić Merluccius merluccius, arbun Pagellus erythrinus.

Glavni cilj ovog preglednog rada je bio stvoriti novu znanstvenu platformu koja bi u bliskoj budućnosti trebala rezultirati boljim mjerama očuvanja koje bi nadalje rezultirale dugoročnim održivim iskorištavanjem živih morskih resursa u Jadranu.
\end{abstract}

Ključne riječi: srdela, brgljun, oslić, arbun, Jadran 